Vol. 18 (2009): 206-222.

\title{
Are there indications of climate change induced increases in variability of major field crops in the northernmost European conditions?
}

\author{
Pirjo Peltonen-Sainio ${ }^{1}$, Lauri Jauhiainen ${ }^{2}$ and Kaija Hakala ${ }^{1}$ \\ MTT Agrifood Research Finland, 'Plant Production Research and ${ }^{2}$ Services Unit, Information Management, \\ FI-31600 Jokioinen, Finland, email: firstname.lastname@mtt.fi
}

\begin{abstract}
As the northern hemisphere will experience the greatest increases in temperature and indications of climatic change are already visible in the north (in the 2000s average temperatures exceeded the long-term mean), we sought to establish if there are already signs of increased variability in yield and quality of the major field crops grown under the northernmost European growing conditions: spring and winter cereals (barley Hordeum vulgare L., oat Avena sativa L., wheat Triticum aestivum L., rye Secale cereale L.), spring rapeseed (turnip rape Brassica rapa L., oilseed rape B. napus L.), pea (Pisum sativum L.) and potato (Solanum tuberosum L.). We used long-term yield datasets of FAO for Finland (1960s to date) and MTT Agrifood Research Finland (MTT) Official Variety Trial datasets on yield and quality of major field crops in Finland since the 1970s. Yield variability was exceptionally high in the 1980s and 1990s, but previously and subsequently national yields were clearly more stable. No progressive increase in yield variability was recorded. No marked and systematic changes in variability of quality traits were recorded, except for rapeseed, which exhibited reduced variability in seed chlorophyll content. This may at least partly attribute to the differences in intensity of input use and thereby responsiveness of the crops before and after 1980 and 1990 decades. We also noted that in the 2000s average temperatures were higher than in earlier decades and this was the case for all months of the growing season except June, which represents, however, the most critical phase for yield determination in most of the field crops in Finland. Also in the 2000s precipitation increased in the first three months of the growing season and thereafter decreased, but without signs of significantly increased numbers of heavy showers (extreme rain events). Hence, in general constant, increased average temperatures during the growing seasons of the 2000s were identified, but with reduced yield variability, which was partly attributable to the diminished use of inputs, especially fertilisers.
\end{abstract}

Key-words: climate, yield, quality, variation, barley, oat, wheat, rye, rapeseed, pea, potato 
Vol. 18 (2009): 206-222.

\section{Introduction}

Northern growing conditions are characterised by cold winters with snowfall, cool summers and precipitation throughout the year. This contrasts with e.g. the Mediterranean countries with their warm conditions, mild winters and warm to hot and dry summers (modified Köppen climate classification, e.g. in www.fao.org//climpag, http://koeppen-geiger. vu-wien.ac.at/ 29.7.2008).

The climatic conditions in the North typically vary considerably (Fig. 1). The major part of within year variation in temperatures is caused by seasonal changes, the average daily temperatures during a year, e.g. in Jyväskylä , Finland ( $62^{\circ} 24^{\prime} \mathrm{N}$, $\left.25^{\circ} 40^{\prime} \mathrm{E}\right)$ varying between $+25^{\circ} \mathrm{C}$ and $-25^{\circ} \mathrm{C}$. In addition, the year-to-year variation in temperatures is higher in Finland than in countries at lower latitudes such as Italy and Germany (Fig. 1).

Despite being variable, some typical features can be found in the North, such as early summer drought or at least insufficient precipitation to sustain vigorous, undisturbed early growth, especially during the phase of yield determination of many of the major field crops grown in Finland (PeltonenSainio et al. 2009a and 2009b). On the other hand, when the growing season proceeds, rains become more frequent and abundant and they may even be damaging for harvest in many ways, causing lodging, a humid microclimate of the plant stands, quality losses, Fusarium spp. invasions and waterlogged soils so that they do not bear harvesting machinery well (Peltonen-Sainio et al. 2009a). Hence, in general, despite the fact that precipitation is generally evenly distributed over the whole year, it is unevenly distributed during the growing season and in a way that does not favour yield and quality formation.

In addition to precipitation, fluctuations also occur in daily mean temperature and depending on cloudiness in radiation. Therefore the radiation to temperature ratio (Fischer 1985), the so-termed photothermal quotient (PTQ) varies, especially in the beginning and end of the growing season. There has been a considerable variation within each decade in these main climatic parameters at the two Finnish locations, Jokioinen in southern Finland and Jyväskylä in Central Finland used in this study (Fig. 2). These two locations represent the main production regions for the crops studied here; spring barley (Hordeum vulgare L.), spring oat (Avena sativa L.), spring and winter wheat (Triticum aestivum L.), winter rye (Secale cereale L.), spring rapeseed (turnip rape Brassica rapa L., oilseed rape B. napus L.), pea (Pisum sativum L.) and potato (Solanum tuberosum L.).

Increased emissions of greenhouse gases have increased the average global surface temperature by $0.76{ }^{\circ} \mathrm{C}$ during the last century (IPCC 2007).

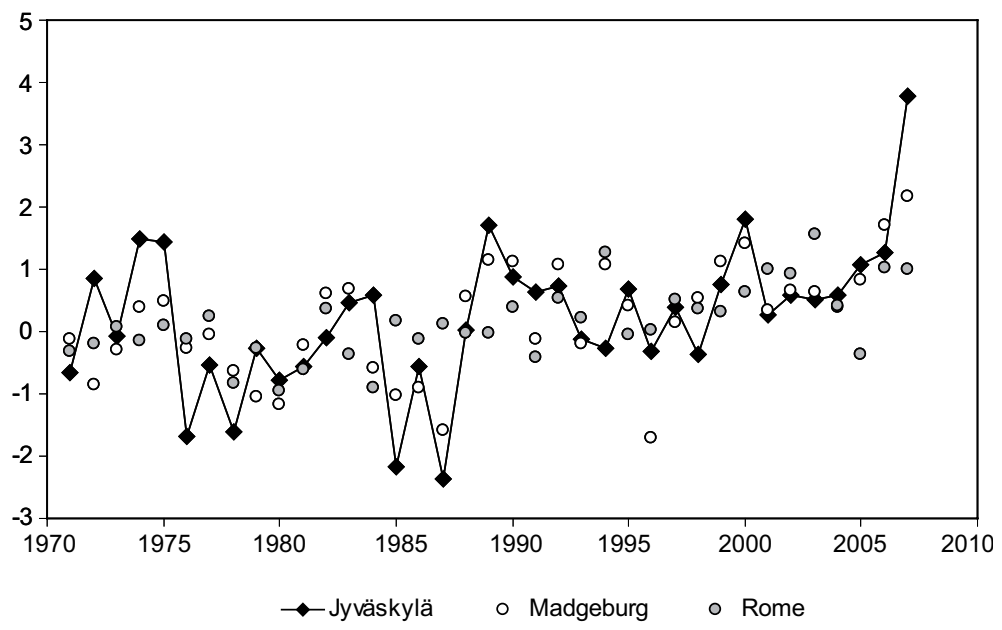

Fig. 1. Differences in annual average temperatures from the long term mean of 1971-2000 in Italy (Rome, 41 ${ }^{\circ} 47^{\prime} \mathrm{N}, 12^{\circ} 35^{\prime} \mathrm{E}$ ), Germany (Magdeburg, $52^{\circ} 06^{\prime} \mathrm{N}$, $11^{\circ} 35^{\prime} \mathrm{E}$ ) and Finland (Jyväskylä, $\left.62^{\circ} 24^{\prime} \mathrm{N}, 25^{\circ} 40^{\prime} \mathrm{E}\right)$. Data from European Climate Assessment \& Dataset (ECA\&D) project, http://eca.knmi.nl/ (Klein Tank et al. 2002). 
Peltonen-Sainio, P. et al. Increases in variablity of field crops

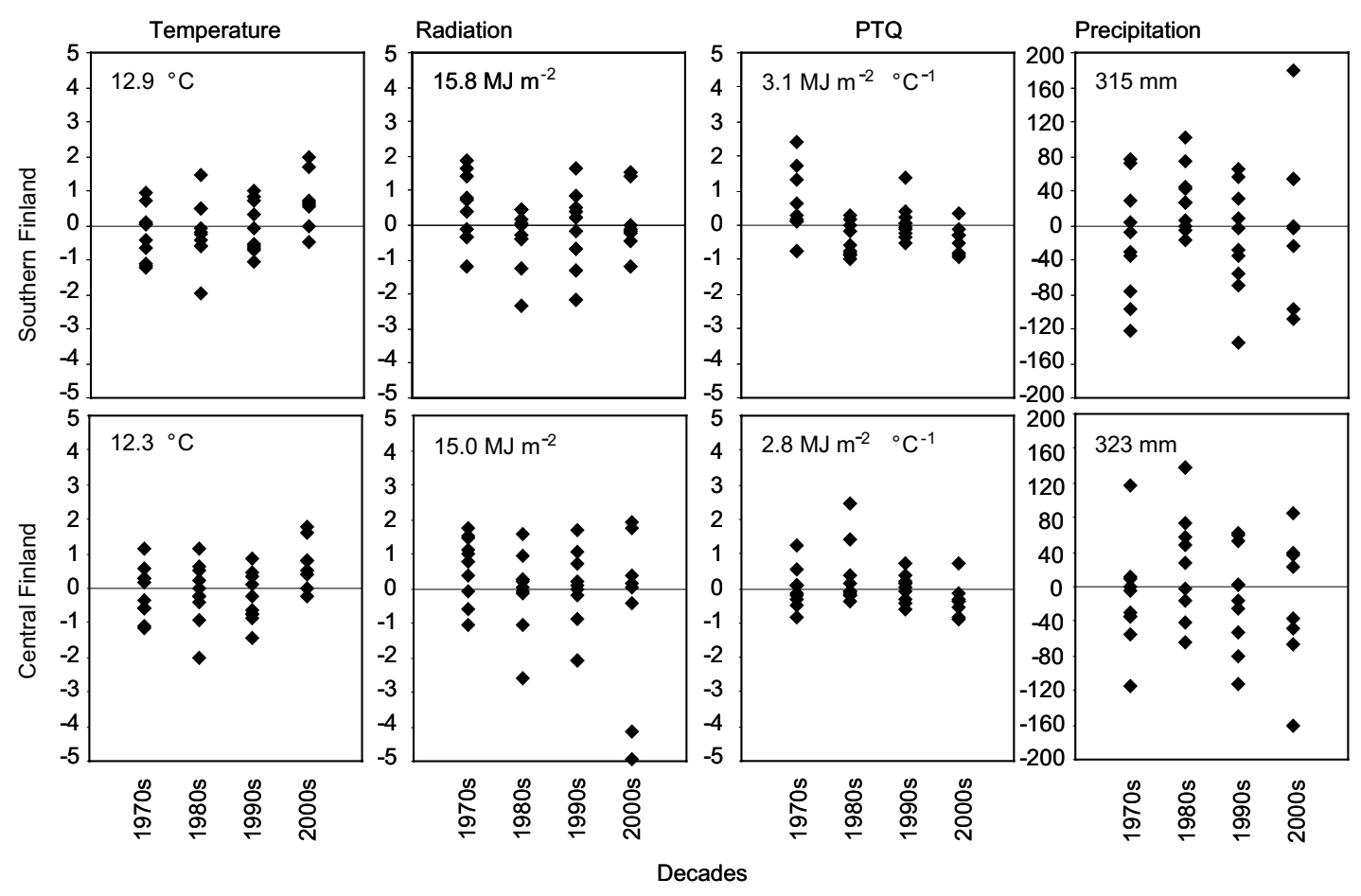

Fig. 2. Deviation of annual averages for temperature $\left({ }^{\circ} \mathrm{C}\right)$, global radiation $\left(\mathrm{MJ} \mathrm{m}^{-2}\right)$, photothermal quotient $\left(\mathrm{PTQ}, \mathrm{MJ} \mathrm{m}^{-2}\right.$ ${ }^{\circ} \mathrm{C}^{-1}$ day $^{-1}$ ) and accumulated precipitation from total mean during growing season (May-September) in different decades in southern (Jokioinen $60^{\circ} 48^{\prime} \mathrm{N}, 23^{\circ} 30^{\prime} \mathrm{E}$ ) and Central Finland (Jyväskylä $\left.62^{\circ} 24^{\prime} \mathrm{N}, 25^{\circ} 40^{\prime} \mathrm{E}\right)$. Total means over growing season and years are shown in each figure. Data from the Finnish Meteorological Institute.

During the last couple of decades the warming has accelerated, 1995-2006 being the warmest period ever recorded (IPCC 2007). This has already resulted in increases in number of warm days and nights and decreases in cold ones, higher precipitation in some areas and lower in others as well as greater variability in temperatures and increases in extreme high temperatures and precipitation events (Klein Tank and Können 2003, Alexander et al. 2006, IPCC 2007). These changes have occurred also in Finland; the growing season has already become several days longer, depending on site, number of frost days has decreased and temperature sums have increased (Klein Tank et al. 2002) (Table 1). As a result of these changes the farmers in Finland have already started to sow spring cereals, sugar beet (Beta vulgaris L. var. altissima) and plant po- tato (Solanum tuberosum L.) earlier (Kaukoranta and Hakala 2008).

Climate warming will continue - the rate of increase in average global temperature depending on greenhouse gas emissions (IPCC 2000). Predictions for the average increase by end of the $21^{\text {st }}$ century vary between $2-4{ }^{\circ} \mathrm{C}$, with a possible range of $1.1-6.4{ }^{\circ} \mathrm{C}$ (IPCC 2007). As a short growing season is one of the main limiting factors to crop production in the North, climate warming and a lengthened growing season could enhance yield potential of many crops and facilitate the introduction of new, more productive crops and varieties (Carter et al. 1996, Olesen and Bindi 2002, Peltonen-Sainio et al. 2009c). In Scandinavia the lengthening will take place particularly in the end of the growing season, while in Finland it will more 
Vol. 18 (2009): 206-222.

Table 1. Development of weather parameters from the 1960 s to present in Jokioinen $\left(60^{\circ} 48^{\prime} \mathrm{N}, 23^{\circ} 30^{\prime} \mathrm{E}\right)$ and Jyväskylä $\left(62^{\circ} 24^{\prime} \mathrm{N}, 25^{\circ} 40^{\prime} \mathrm{E}\right)$. Adapted from data sets available at the website of the European Climate Assessment \& Dataset (ECA\&D) project, http://eca.knmi.nl/ (Klein Tank et al., 2002). ANN, annual, DJF, winter, MAM, spring, JJA, summer, SON, autumn. $\mathrm{d}=$ days, $\mathrm{dd}=$ degree days $\left(\right.$ over $\left.+4{ }^{\circ} \mathrm{C}\right) .+0=$ no change.

\begin{tabular}{|c|c|c|}
\hline Weather parameter & Jokioinen & Jyväskylä \\
\hline Temperature sum dd & $\begin{array}{l}\mathrm{ANN}+235 \mathrm{dd}, \mathrm{MAM}+65 \\
\mathrm{JJA}+85, \mathrm{SON}+75\end{array}$ & $\mathrm{ANN}+170 \mathrm{dd}, \mathrm{MAM}+30, \mathrm{JJA}+100, \mathrm{SON}+40$ \\
\hline Growing season length & $+10 \mathrm{~d}$ & $+7 \mathrm{~d}$ \\
\hline Number of frost days & $-30 \mathrm{~d}$ & $-15 \mathrm{~d}$ \\
\hline Number of hot days $\left(>25^{\circ} \mathrm{C}\right)$ & $+6 \mathrm{~d}$ & $+4 \mathrm{~d}$ \\
\hline Intra-period temperature extreme range & $\begin{array}{l}\text { ANN V } 3{ }^{\circ} \mathrm{C}, \mathrm{DJF}-4{ }^{\circ} \mathrm{C}, \\
\mathrm{MAM}-4{ }^{\circ} \mathrm{C}, \mathrm{JJA} \pm 0{ }^{\circ} \mathrm{C} \\
\mathrm{SON} \pm 0{ }^{\circ} \mathrm{C}\end{array}$ & $\begin{array}{l}\mathrm{ANN}-2{ }^{\circ} \mathrm{C}, \mathrm{DJF}-2{ }^{\circ} \mathrm{C}, \mathrm{MAM}-5{ }^{\circ} \mathrm{C}, \mathrm{JJA} \pm 0{ }^{\circ} \mathrm{C}, \\
\mathrm{SON} \pm 0{ }^{\circ} \mathrm{C}\end{array}$ \\
\hline Mean of diurnal temperature range & $\begin{array}{l}\mathrm{ANN}-0.3{ }^{\circ} \mathrm{C}, \mathrm{DJF}-0.5^{\circ} \mathrm{C} \\
\mathrm{MAM} \pm 0{ }^{\circ} \mathrm{C}, \mathrm{JJA} \pm 0{ }^{\circ} \mathrm{C} \\
\mathrm{SON} \pm 0{ }^{\circ} \mathrm{C}\end{array}$ & $\begin{array}{l}\mathrm{ANN}-0.5^{\circ} \mathrm{C}, \mathrm{DJF}-0.5^{\circ} \mathrm{C}, \mathrm{MAM} \pm 0{ }^{\circ} \mathrm{C}, \mathrm{JJA} \pm 0 \\
{ }^{\circ} \mathrm{C}, \mathrm{SON} \pm 0^{\circ} \mathrm{C}\end{array}$ \\
\hline
\end{tabular}

affect the beginning (Carter 1998). This will also benefit the crop growth most, as rapid decline in light levels at high latitudes in the autumn (www. gaisma.com) greatly limits growth, even when temperature would still allow it. However, changes in precipitation will substantially affect the extent to which this increased yield potential will be realised as harvested yield (Peltonen-Sainio et al. 2009b). Also other challenges may increase, including changes in overwintering conditions of autumn sown crops (Jylhä et al. 2008), when the current typically cold winters will be gradually replaced by mild winters typical of Central Europe.

When considering the opportunities for farmers to manage crop production through controlling prevailing conditions, the greatest challenge is often represented by fluctuations in conditions, which makes it hard to both anticipate the forthcoming growing conditions and to plan environmentally and economically feasible input use, especially regarding fertiliser application. With climate change extreme events are expected to become more frequent, and fluctuating conditions will further challenge both the economic and environmental sustainability of crop production. As there are already many indications of global warming, especially in the northern hemisphere, and also increased inci- dence of weather extremes (Klein Tank and Können 2003, Alexander et al. 2006, IPCC 2007), the main objective of this study was to identify existing changes in yield and quality variability of the main field crops (cereals, rapeseed, pea and potato) and relate it to changes in climatic conditions.

\section{Material and methods}

\section{Yields from FAO datasets}

Yields of spring barley, spring oat, winter rye, dry pea, green pea and potato as well as joint data of spring (dominant type) and winter wheat, and spring rapeseed (turnip rape predominates over oilseed rape) for Finland were obtained from FAOSTAT (www.fao.org) for the period from 1961 to 2006. These data represent country wide yield based on annual farm surveys. The data were used for analysis of within decade variability. This was analysed in two ways: 1) by fitting a trend curve and comparing the difference between the estimated and observed yields for each year, calculating their mean and sum (from absolute values) for each decade and 


\section{AGRICULTURAL AND FOOD SCIENCE}

\section{Peltonen-Sainio, P. et al. Increases in variablity of field crops}

2) by calculating the coefficient of variation (CV) of yields within each decade. When total sums of absolute values of differences between estimated and observed yields were calculated we took into account that in the 1960s the number of years was nine and in the 2000s seven, and multiplied their sums accordingly. We also did some additional analyses to check whether decade-based evaluation of yield variability detected the most and least variable years by comparing the results to those gained by use of five and ten years moving averages. As they were analogous, we decided to use the decadebased approach.

\section{Yield and quality from MTT multi- location datasets}

MTT long-term field experiments in cereals and pea were conducted in 1970-2007, in rapeseed 1976-2007 and in potato 1970-2004 at a total of 15-26 different locations in Finland depending on crops and their most typical production areas. The experiments were part of the MTT Official Variety Trials and all followed procedures specified for that purpose (Kangas et al. 2005). In addition to the fields at MTT, which has numerous regional research units in Finland, some of the experiments were organised by plant breeding companies and private agricultural research stations.

All experiments were conducted as randomised complete block designs or incomplete block designs. The numbers of replicates were three to four. Each year the tested set of cultivars and breeding lines changed, but long term-check cultivars were also used. The number of long-term check cultivar was 2, 3 or 4, depending on species. Each check cultivar was included to testing program during 10-15 years. All check cultivars of one species was not changed at the same time, which ensures that the results of different years are comparable. In addition, a new check cultivar was selected so that it's testing history reach up to $4-8$ years. Annual turnover of cultivars and breeding lines was usually less than $20 \%$, which made it possible to separate effects of genotype and environment. Plots were 7-10 $\mathrm{m} \times 1.25 \mathrm{~m}$ in grain and seed producing crops and $8-10 \mathrm{~m} \times 1.50 \mathrm{~m}$ in potato, depending on location and year. Seeding rate depended on crop, conforming to the commonly used seeding rates in Finland without any major changes over time. Weeds were chemically controlled with herbicides commonly used in each time period. Diseases were not routinely controlled with fungicides to allow differences among entries in disease resistance to be recorded. Fertiliser use depended on cropping history, soil type and fertility, and was comparable with standard practices in Finland, i.e., reduced fertiliser phosphorus use since 1995.

Close to maturity plant height $(\mathrm{cm})$ was taken as a mean of three measurements per plot. Lodging $(\%)$ was assessed as the average lodged area as a proportion of the plant stand, close to harvest (100 corresponding to total lodging). The plots of cereals, rapeseed and pea were combine-harvested and grain or seed yield weighed (tonnes ha- ${ }^{-1}$ ) after removing straw, weed seeds and other particles. Grain or seed moisture content was determined by weighing samples before and after oven drying, or more recently by using a Dickey John apparatus. Seed yield was adjusted to 15,9 and $15 \%$ moisture content in cereals, rapeseed and pea, respectively. In cereals, single grain weight $\left(\mathrm{mg} \mathrm{grain}^{-1}\right)$ was measured from yield samples of 100 grains, each five times, disregarding the lowest and highest recordings from the calculations of mean. Numbers of grains per square metre were calculated by dividing grain yield per square metre by single grain weight. Grain protein content (\%) was determined using the Kjeldahl-method. Similar yield component and quality measurements were carried out also in pea and rapeseed. In rapeseed also seed oil content (\%) was determined by heptane-alcohol extraction and converted to dry matter and seed chlorophyll content $\left(\mathrm{mg} \mathrm{kg}^{-1}\right)$ by spectrophotometry. Furthermore, starch content (\%) of potato tubers was analysed as shown in http://www.starch.dk/isi/ methods/starchct.htm.

The effects of environment and genotype were separated by the following statistical model:

$\mathrm{y}_{\mathrm{ij}}=\mu+$ experiment $_{\mathrm{i}}+$ cultivar $_{\mathrm{j}}+\varepsilon_{\mathrm{ij}}$ 
Vol. 18 (2009): 206-222.

where $y_{i j}$ is observed value for $j$ th cultivar in ith experiment, while $\mu$, experimenti, cultivarj and $\varepsilon_{\mathrm{ij}}$ are intercept, the effect of ith experiment, the effect of jth cultivar and residual effect, respectively. Yield differences between experimental sites were relatively large and regular so the effect of site was added to the model when yield was analysed.

Genetic variation was excluded from the effect of experiments and therefore experiment ${ }_{i}$ was used to measure within year variability. The standard deviation of the estimated experiment ${ }_{i}$ values from the same year was used to describe this variability. Similarly, the mean of estimated experiment ${ }_{i}$ values from the same year was selected to represent the mutually comparable average yield or quality of the year.

\section{Climate datasets}

Daily values of mean temperature $\left({ }^{\circ} \mathrm{C}\right)$, precipitation $(\mathrm{mm})$, global radiation $\left(\mathrm{MJ} \mathrm{m}^{-2}\right)$ and photothermal quotient [calculated as the ratio of radiation to daily mean temperature (above $+5{ }^{\circ} \mathrm{C}$ ) ratio, $\mathrm{MJ}$ $\mathrm{m}^{-2}{ }^{\circ} \mathrm{C}^{-1} \mathrm{~d}^{-1}$ ] from 1970 to 2007 from the Finnish Meteorological Institute were used for calculation of monthly means from May to September. These months cover the typical growing season in Finland. Also means for the whole period from May to September were calculated for each year and deviations from the decade means were estimated. Thus, annual variability in all the climatic parameters within each decade was compared. Also monthly, decadic deviations from the whole period monthly means were calculated in temperature, radiation and PTQ. Montly amounts of accumulated precipitation were dealt with correspondinly. The possible change in occurrence of heavy precipitation events was further studied by computing the monthly frequencies of rains exceeding $5 \mathrm{~mm}, 10 \mathrm{~mm}$ and $20 \mathrm{~mm}$ in different decades. All these measurements were carried out for two locations in Finland: Jokioinen in southern Finland $\left(60^{\circ} 48^{\prime} \mathrm{N}, 23^{\circ} 30^{\prime} \mathrm{E}\right)$ and Jyväskylä in Central Finland $\left(62^{\circ} 24^{\prime} \mathrm{N}, 25^{\circ} 40^{\prime} \mathrm{E}\right)$, which represent the main production regions of the crops studied.
Linear and quadratic polynomial regression models were used to estimate correlation between yield and monthly precipitation. Again, estimated experiment $_{i}$ values were used for yield to exclude bias from genetic variation. All statistical analyses were performed by SAS software (version 9.1) using MIXED and REG procedures.

\section{Results}

\section{Yield variability between decades}

Substantial variation between years was recorded in yields of cereals, rapeseed, pea and potato in the FAO datasets from 1961 to 2006. Potato was the only crop whose yields increased throughout the studied period, while the trends for all the grain and seed crops levelled off or even decreased, green pea most but also dry pea and rapeseed (Fig. 3 ). When comparing the deviations of recorded yields from the trend line, periodical fluctuations were identified. Both timing and degree of deviation depended on species. Coefficient of variation of yield for each decade indicated for all crops that the highest variation occurred either in the 1980s and/or the 1990s (Table 2). Rapeseed was the only exception to this as very high variation in yields was recorded in the 1960s, but also in rapeseed yield variability was higher in the 1980s and 1990s than in the 1970s and 2000s. In the 1960s rapeseed was grown as a novel crop on only about 6000 hectares, which is less than one tenth of the area sown in recent decades. However, in general, the extent of cultivation was not correlated with the degree of yield variability.

One striking result was that despite the increasing yield variability into the 1980s and 1990s in cereals and pea, the least variation occurred in the 2000 s as compared with any other decades when measured by the CV. This was also true in many cases when comparing differences between actual yields and estimated trend yields (Figs 3 and 4). Differences between decades were particularly clear when expressed as total decadal sums of de- 
Peltonen-Sainio, P. et al. Increases in variablity of field crops
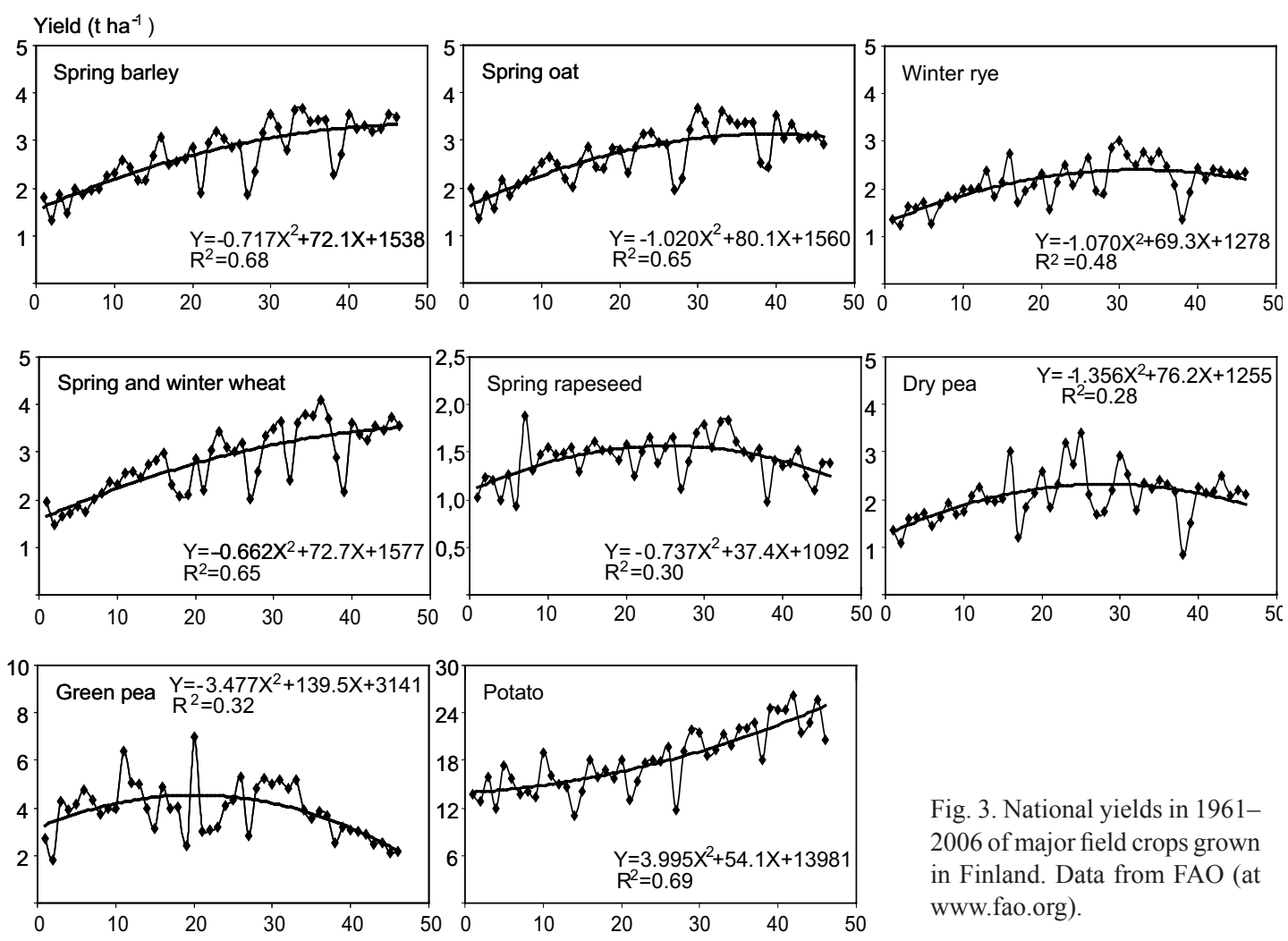

Fig. 3. National yields in 19612006 of major field crops grown in Finland. Data from FAO (at www.fao.org).

Number of years after 1960

Table 2. Coefficient of variation (CV) for national yields of major field crops and mean harvested area (1000 ha) for each of the last five decades and over the whole period in Finland. Data from FAO (at www.fao.org).

\begin{tabular}{|c|c|c|c|c|c|c|c|c|c|c|c|c|c|c|c|c|}
\hline \multirow[t]{2}{*}{ Decade } & \multicolumn{2}{|c|}{ Spring barley } & \multicolumn{2}{|c|}{ Spring oat } & \multicolumn{2}{|c|}{ Winter rye } & \multicolumn{2}{|c|}{ Wheat* } & \multicolumn{2}{|c|}{ Rapeseed* } & \multicolumn{2}{|c|}{ Dry pea } & \multicolumn{2}{|c|}{ Green pea } & \multicolumn{2}{|c|}{ Potato } \\
\hline & $\mathrm{CV}$ & ha & $\mathrm{CV}$ & ha & $\mathrm{CV}$ & ha & $\mathrm{CV}$ & ha & $\mathrm{CV}$ & ha & $\mathrm{CV}$ & ha & $\mathrm{CV}$ & ha & $\mathrm{CV}$ & ha \\
\hline $1960 \mathrm{~s}$ & 0.16 & 286 & 0.16 & 469 & 0.14 & 89 & 0.14 & 245 & 0.23 & 6 & 0.15 & 2 & 0.24 & $<1$ & 0.12 & 70 \\
\hline 1970s & 0.11 & 497 & 0.10 & 508 & 0.14 & 54 & 0.12 & 171 & 0.06 & 16 & 0.22 & 5 & 0.26 & $<1$ & 0.14 & 49 \\
\hline $1980 \mathrm{~s}$ & 0.18 & 577 & 0.16 & 423 & 0.17 & 39 & 0.16 & 141 & 0.13 & 67 & 0.25 & 5 & 0.31 & 1 & 0.18 & 41 \\
\hline $1990 \mathrm{~s}$ & 0.14 & 526 & 0.13 & 366 & 0.20 & 26 & 0.19 & 117 & 0.16 & 67 & 0.28 & 8 & 0.22 & 2 & 0.10 & 35 \\
\hline $2000 \mathrm{~s}$ & 0.04 & 550 & 0.07 & 389 & 0.03 & 28 & 0.04 & 185 & 0.10 & 74 & 0.06 & 4 & 0.15 & 2 & 0.09 & 29 \\
\hline $\begin{array}{l}\text { Whole } \\
\text { period }\end{array}$ & 0.24 & 487 & 0.21 & 433 & 0.21 & 8 & 0.25 & 169 & 0.16 & 45 & 0.25 & 5 & 0.29 & 1 & 0.22 & 45 \\
\hline
\end{tabular}

* Wheat includes both spring and winter wheat; Rapeseed includes both spring turnip rape and spring oilseed rape 
Vol. 18 (2009): 206-222.

Difference between estimated and observed yield in absolute values $\left(\mathrm{t} \mathrm{ha}^{-1}\right)$

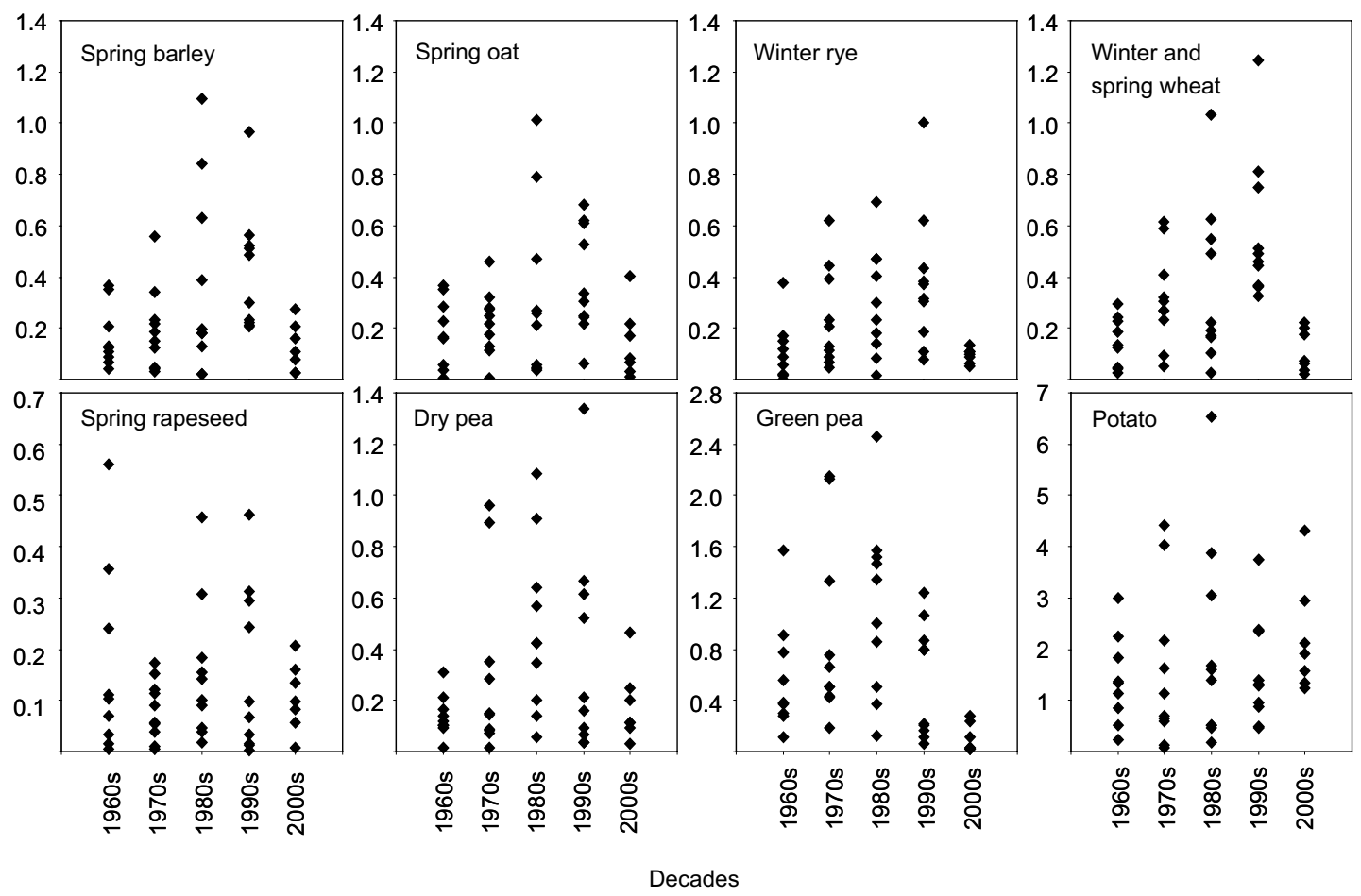

Fig. 4. Difference between estimated and observed yield in absolute values of major field crops grown in Finland during different decades. In the 1960s and 2000s nine and seven years were included, respectively. Data from FAO (at www. fao.org).

viations (in absolute values) of actual yields from whole period trends (Table 3). For cereals and dry pea such total decadal sums of variation were highest in the 1980s and 1990s - more than double that in the 2000s. In general, this was also true for rapeseed, but not for green pea and potato. Further, the mean difference between actual and trend yields contrasted in all crop species when comparing the 1980s and 1990s. In all cereals, rapeseed, green pea and potato actual yields during the 1980s were lower than estimated and higher in the 1990s. In dry pea, however, the yield deviations of the two decades were just contrary to those of other crops (Table 3).

\section{Within year yield and quality variability}

FAO datasets can only be used for comparing variation between years and decades and hence, we used data from MTT long-term, multi-location Official Variety Trials to study the within year variation attributable to locations. When measuring the within year SD, we used long-term check cultivars to account for the genetic variation and thereby be better able to study environmental variation. Similarly as for the recorded variability in national yields (Figs 3 and 4), the range of within year variation was high in the 1980s and 1990s, especially in cereals (Fig. 5). Barley was, however, an exception to this. Within year variation in yields increased in barley as in rapeseed from one decade to the next, while 


\section{Peltonen-Sainio, P. et al. Increases in variablity of field crops}

Table 3. Difference (diff) between estimated and observed national yields $\left(\mathrm{kg} \mathrm{ha}^{-1}\right)$ as means and total sum $(\Sigma$, for absolute value of differences) for each of the last five decades in Finland. Data from FAO (at www.fao.org). Annual values for observed and estimated yields (with equation used for calculations) shown in Figure 2.

\begin{tabular}{|c|c|c|c|c|c|c|c|c|c|c|c|c|c|c|c|c|}
\hline \multirow[t]{2}{*}{ Decade } & \multicolumn{2}{|c|}{ Spring barley } & \multicolumn{2}{|c|}{ Spring oat } & \multicolumn{2}{|c|}{ Winter rye } & \multicolumn{2}{|c|}{ Wheat* } & \multicolumn{2}{|c|}{ Rapeseed* } & \multicolumn{2}{|c|}{ Dry pea } & \multicolumn{2}{|c|}{ Green pea } & \multicolumn{2}{|c|}{ Potato } \\
\hline & diff & $\Sigma$ & $\operatorname{diff}$ & $\Sigma$ & diff & $\Sigma$ & $\operatorname{diff}$ & $\Sigma$ & diff & $\Sigma$ & diff & $\Sigma$ & diff & $\Sigma$ & diff & $\Sigma$ \\
\hline$\overline{1960 s}$ & -38 & 1642 & 1 & 1836 & -20 & 1109 & -35 & 1479 & 2 & 1661 & -30 & 1395 & 20 & 5842 & -17 & 13921 \\
\hline 1970 s & 85 & 1935 & 2 & 2212 & 35 & 2349 & 13 & 3153 & 22 & 820 & -39 & 3044 & -111 & 9069 & 46 & 15511 \\
\hline 1980s & -153 & 3680 & -144 & 3191 & -92 & 2977 & -72 & 3580 & -79 & 1536 & 85 & 4797 & -158 & 11218 & -434 & 19807 \\
\hline 1990s & 57 & 4220 & 114 & 3842 & 32 & 3792 & 67 & 5760 & 52 & 1541 & -145 & 3741 & 315 & 5526 & 414 & 15271 \\
\hline $2000 \mathrm{~s}$ & 65 & 1263 & 39 & 1403 & 62 & 932 & 32 & 1136 & 6 & 1068 & 180 & 1804 & -91 & 1056 & -16 & 22065 \\
\hline $\begin{array}{l}\text { Whole pe- } \\
\text { riod ratio" }\end{array}$ & & 18 & 8 & .6 & & 1.0 & & 1.3 & & 9.3 & 14 & 4.9 & & 7.8 & & 9.4 \\
\hline
\end{tabular}

* Wheat includes both spring and winter wheat; Rapeseed includes both spring turnip rape and spring oilseed rape

\# Ratio (\%) calculated for each crop species as the whole period annual mean for absolute value of differences between estimated and observed yields divided by whole period annual mean yield and by multiplying by one hundred

Range within each decade in within year variation in harvested yield $\left(\mathrm{t} \mathrm{ha}^{-1}\right)$
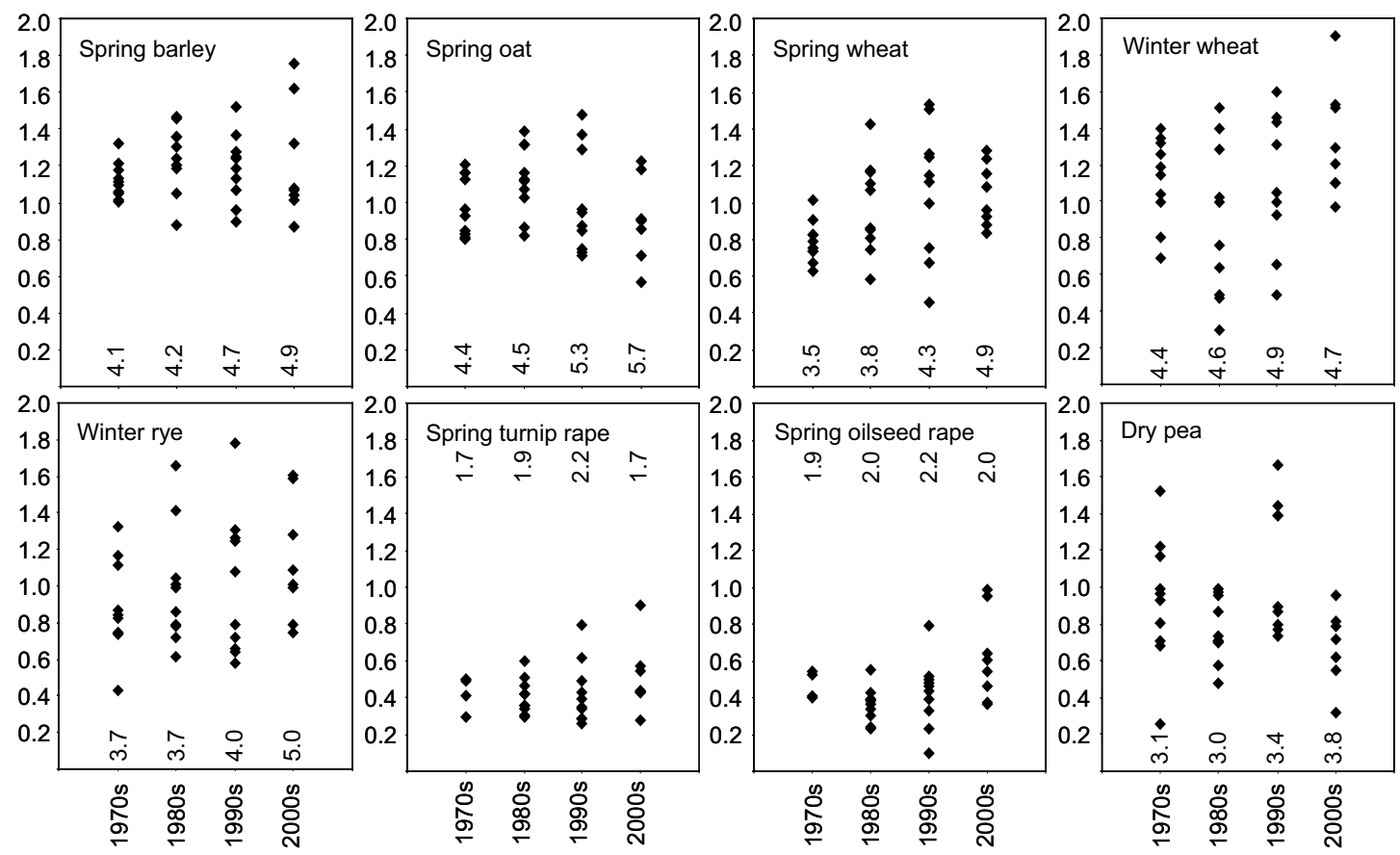

Decades

Fig. 5. Range (tonnes $\mathrm{ha}^{-1}$ ) of within year variation of long-term check cultivars in harvested yield during each of five decades. Also average yields (tonnes ha ${ }^{-1}$ ) over all cultivars and each decade are shown (numbers above or below the columns) for each crop. In the 1970s and 2000s four years of data were included for rapeseed, while for all crops in the 2000s seven were included. Data from MTT Official Variety Trials. 
Vol. 18 (2009): 206-222.

in pea it fluctuated among decades. Furthermore, our results indicated that in most cases both single grain weight and number of grains per square metre increased from one decade to the next (Table 4) contrary to the decade means of the long-term check cultivars (data not shown). Grain number had a far higher range of variability than single grain weight, which was also the case for rapeseed (Table 5). Also

Table 4. Decade means over all cultivars and within year variation of long-term check cultivars (shown as S.D. range) for yield, grain weight, number of grains per square metre, grain protein content, plant height and lodging in cereals and pea grown in MTT Official Variety Trials.

\begin{tabular}{|c|c|c|c|c|c|}
\hline $\begin{array}{l}\text { Crop and } \\
\text { decade }\end{array}$ & $\begin{array}{l}\text { Single grain weight } \\
\qquad(\mathrm{mg})\end{array}$ & $\begin{array}{l}\text { Grains } \mathrm{m}^{-2} \\
(\text { no. } \times 100)\end{array}$ & $\begin{array}{c}\text { Protein content } \\
\qquad(\%)\end{array}$ & $\begin{array}{l}\text { Plant height } \\
(\mathrm{cm})\end{array}$ & $\begin{array}{l}\text { Lodging } \\
\quad(\%)\end{array}$ \\
\hline \multicolumn{6}{|c|}{ Spring barley: } \\
\hline $1970 \mathrm{~s}$ & $38.9(2.7-4.4)$ & $106.9(19.3-30.8)$ & $13.7(0.9-2.4)$ & $71(8-17)$ & $32(11-28)$ \\
\hline $1980 \mathrm{~s}$ & $39.6(2.4-7.0)$ & $107.4(26.9-33.9)$ & $12.6(1.4-2.2)$ & $77(11-18)$ & $23(9-33)$ \\
\hline $1990 \mathrm{~s}$ & $43.0(2.2-5.4)$ & $112.8(18.5-35.2)$ & $12.1(0.8-1.9)$ & $72(7-5)$ & $17(7-31)$ \\
\hline $2000 \mathrm{~s}$ & $45.0(2.5-6.5)$ & $114.7(21.1-32.6)$ & $12.5(0.8-1.8)$ & $69(7-14)$ & $14(2-28)$ \\
\hline \multicolumn{6}{|l|}{ Spring oat: } \\
\hline $1970 \mathrm{~s}$ & $33.0(1.7-3.2)$ & $133.2(21.4-35.4)$ & $13.7(0.7-2.2)$ & $90(11-17)$ & $34(2-49)$ \\
\hline $1980 \mathrm{~s}$ & $32.9(1.7-4.9)$ & $138.1(22.6-42.9)$ & $13.4(1.1-2.1)$ & $90(9-19)$ & $25(7-43)$ \\
\hline $1990 \mathrm{~s}$ & $35.8(1.8-3.5)$ & $149.3(19.4-39.9)$ & $13.0(1.0-1.7)$ & $94(8-19)$ & $20(11-49)$ \\
\hline $2000 \mathrm{~s}$ & $38.0(1.3-5.2)$ & $152.7(22.5-40.5)$ & $13.4(0.8-1.5)$ & $90(9-13)$ & $22(10-47)$ \\
\hline \multicolumn{6}{|l|}{ Winter rye: } \\
\hline $1970 \mathrm{~s}$ & $26.4(1.7-4.1)$ & $143.4(18.5-52.2)$ & $13.6(0.8-2.5)$ & $128(10-23)$ & $56(15-32)$ \\
\hline $1980 \mathrm{~s}$ & $29.5(2.1-4.5)$ & $127.5(25.8-53.5)$ & $11.8(1.1-2.0)$ & $138(8-21)$ & $46(19-29)$ \\
\hline $1990 \mathrm{~s}$ & $30.5(1.5-4.4)$ & $133.7(13.6-56.5)$ & $11.4(0.6-1.8)$ & $138(3-21)$ & $49(14-30)$ \\
\hline $2000 \mathrm{~s}$ & $34.4(2.5-8.7)$ & $150.0(26.0-61.6)$ & $10.9(0.7-1.6)$ & $125(8-21)$ & $38(3-41)$ \\
\hline \multicolumn{6}{|c|}{ Spring wheat: } \\
\hline $1970 \mathrm{~s}$ & $34.7(2.5-5.2)$ & $100.2(9.4-25.8)$ & $15.5(1.0-2.2)$ & $82(-14)$ & $24(4-28)$ \\
\hline $1980 \mathrm{~s}$ & $35.4(2.7-4.4)$ & $106.2(11.4-36.7)$ & $14.2(1.2-2.3)$ & $86(4-16)$ & $19(3-29)$ \\
\hline $1990 \mathrm{~s}$ & $37.8(1.7-4.9)$ & $113.7(15.0-36.0)$ & $14.0(1.1-2.7)$ & $83(4-15)$ & $12(5-17)$ \\
\hline $2000 \mathrm{~s}$ & $38.4(1.1-6.1)$ & $128.3(19.5-34.6)$ & $13.9(0.7-2.0)$ & $80(4-12)$ & $7(2-13)$ \\
\hline \multicolumn{6}{|c|}{ Winter wheat: } \\
\hline $1970 \mathrm{~s}$ & $38.6(1.3-4.5)$ & $115.3(12.0-34.7)$ & $14.3(0.7-1.8)$ & $92(6-16)$ & $29(3-35)$ \\
\hline $1980 \mathrm{~s}$ & $40.2(0.6-5.0)$ & $115.2(11.3-35.4)$ & $11.8(0.7-1.7)$ & $99(4-16)$ & $24(4-33)$ \\
\hline $1990 \mathrm{~s}$ & $43.1(1.7-6.4)$ & $115.3(11.5-39.0)$ & $12.0(0.4-1.3)$ & $93(7-16)$ & $24(4-29)$ \\
\hline $2000 \mathrm{~s}$ & $43.2(1.9-4.8)$ & $113.7(15.9-48.3)$ & $12.7(0.5-2.0)$ & $81(4-12)$ & $11(2-16)$ \\
\hline \multicolumn{6}{|l|}{ Dry pea: } \\
\hline $1970 \mathrm{~s}$ & $216.1(13.6-28.9)$ & $14.6(1.4-6.4)$ & $23.9(0.2-2.9)$ & $77(11-30)$ & $63(10-19)$ \\
\hline $1980 \mathrm{~s}$ & $232.6(10.4-43.7)$ & $13.0(2.6-4.6)$ & $22.3(1.0-4.4)$ & $59(8-24)$ & $57(14-31)$ \\
\hline $1990 \mathrm{~s}$ & $237.2(8.3-28.8)$ & $14.6(2.4-6.4)$ & $20.9(1.6-3.7)$ & $53(4-19)$ & $36(7-34)$ \\
\hline $2000 \mathrm{~s}$ & $264.0(8.9-38.8)$ & $14.4(1.2-3.3)$ & $22.4(0.9-3.0)$ & $75(6-16)$ & $44(4-39)$ \\
\hline
\end{tabular}




\section{Peltonen-Sainio, P. et al. Increases in variablity of field crops}

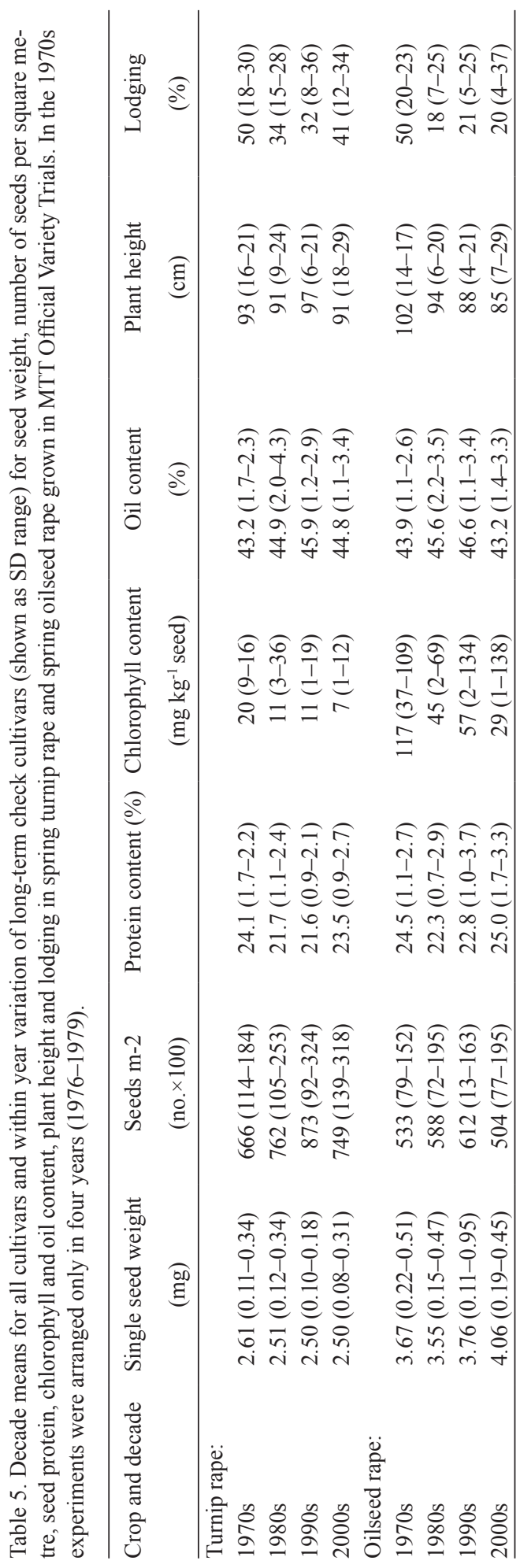

differences between decades in range of variation in grain number were recorded. In spring wheat, turnip rape and winter rye, increasing variability from the 1970s until the current decade was identified.

Within year variability in quality traits fluctuated depending on decade. In some decades protein content seemed to be more stable than in others: like the 2000s for oat and winter rye (Table 4). However, no clear trend of change in variability of grain or seed protein content was recorded. Similarly, the range of variation in oil content of rapeseed seemed to fluctuate from one decade to another, though that in seed chlorophyll content declined (Table 5). No systematic environmentally induced changes in range of variation in potato tuber yield or starch content were found (Table 6).

Variability in pea plant height was consistently reduced over time (Table 4). Contrary to this, it increased both in oilseed rape and turnip rape (Table 5). However, in cereals, variation in plant height was quite equal until a slight decrease in the 2000s. Range of variability in lodging did not change in parallel with plant height. The most evident decrease in variability of lodging was found in spring and winter wheat simultaneously with reduced decadal mean lodging. In contrast, range of variation in lodging of oilseed rape and turnip rape somewhat increased.

Table 6. Decade means for all cultivars and within year variation of long-term check cultivars (shown as SD range) for tuber yield and tuber starch content in potato grown in MTT Official Variety Trials. In the 2000s experiments were arranged only in five years (2000-2004).

\begin{tabular}{lcc}
\hline Decade & $\begin{array}{c}\text { Yield } \\
\left(\mathrm{t} \mathrm{ha}^{-1}\right)\end{array}$ & $\begin{array}{c}\text { Starch content } \\
(\%)\end{array}$ \\
\hline $1970 \mathrm{~s}$ & $32.7(4.6-9.0)$ & $15.1(0.8-1.9)$ \\
$1980 \mathrm{~s}$ & $34.1(5.1-10.2)$ & $14.9(1.1-2.0)$ \\
$1990 \mathrm{~s}$ & $37.2(5.6-10.5)$ & $15.9(0.7-1.7)$ \\
$2000 \mathrm{~s}$ & $42.9(5.7-9.5)$ & $16.2(1.3-1.8)$ \\
\hline
\end{tabular}


Vol. 18 (2009): 206-222.

\section{Fluctuations in climatic parameters}

Because we noticed that, in general, between and within year variations were often highest in the 1980s and 1990s, we first studied possible similarities between variability of yield and climate. Mean temperature range for the growing season did not markedly differ from one decade to another except in the 2000s and this was true for both southern and Central Finland (Fig. 2). In the 2000s above average growing season temperatures (up to $2{ }^{\circ} \mathrm{C}$ higher than average) were recorded, but the range is as wide as in preceding decades with their ranges distributed evenly to both sides of the total mean measured over the whole study period. When studying this further by comparing each month of the growing season separately in all four decades, we found above average monthly temperatures for the 2000s in all months but June (Table 7). This contrasted with what was found for the 1970s. In addition to these recorded differences between decades, temperature range between growing seasons was slightly more

Table 7. Difference between total and decade means for daily average temperature, global radiation, photothermal quotient (PTQ) and accumulated precipitation for each month of the growing season in southern Finland (Jokioinen) and central Finland (Jyväskylä). Data from the Finnish Meteorological Institute.

\begin{tabular}{|c|c|c|c|c|c|c|c|c|}
\hline \multirow[b]{2}{*}{$\begin{array}{l}\text { Month and } \\
\text { decade }\end{array}$} & \multicolumn{4}{|c|}{ Southern Finland } & \multicolumn{4}{|c|}{ Central Finland } \\
\hline & $\begin{array}{c}\text { Temperature } \\
\left({ }^{\circ} \mathrm{C}\right)\end{array}$ & $\begin{array}{l}\text { Radiation } \\
\left(\mathrm{MJ} \mathrm{m}^{-2}\right)\end{array}$ & $\begin{array}{c}\text { PTQ } \\
\left(\mathrm{MJ} \mathrm{m}^{-2}{ }^{\circ} \mathrm{C}^{-1}\right)\end{array}$ & $\begin{array}{l}\text { Precipitation } \\
\quad(\mathrm{mm})\end{array}$ & $\begin{array}{c}\text { Temperature } \\
\left({ }^{\circ} \mathrm{C}\right)\end{array}$ & $\begin{array}{l}\text { Radiation } \\
\left(\mathrm{MJ} \mathrm{m}^{-2}\right)\end{array}$ & $\begin{array}{c}\text { PTQ } \\
\left(\mathrm{MJ} \mathrm{m}^{-2}{ }^{\circ} \mathrm{C}^{-1}\right)\end{array}$ & $\begin{array}{c}\text { Precipitation } \\
\quad(\mathrm{mm})\end{array}$ \\
\hline \multicolumn{9}{|l|}{ May: } \\
\hline $1970 \mathrm{~s}$ & -0.1 & 0.7 & 2.0 & -9.9 & 0.1 & 0.6 & 0.2 & -11.9 \\
\hline $1980 \mathrm{~s}$ & 0.3 & -0.2 & -1.8 & 7.2 & 0.4 & 0.1 & 0.1 & 7.9 \\
\hline $1990 \mathrm{~s}$ & -0.5 & 0.0 & 0.5 & -2.8 & -0.9 & -0.1 & -0.2 & -4.0 \\
\hline $2000 \mathrm{~s}$ & 0.3 & -0.5 & -1.2 & 6.6 & 0.4 & -0.8 & -0.4 & 9.8 \\
\hline \multicolumn{9}{|l|}{ June: } \\
\hline $1970 \mathrm{~s}$ & 0.2 & 1.9 & 0.2 & -19.8 & 0.3 & 2.2 & 0.2 & -13.6 \\
\hline $1980 \mathrm{~s}$ & -0.2 & -0.8 & 0.1 & 7.3 & -0.1 & 0.3 & 0.3 & 8.4 \\
\hline $1990 \mathrm{~s}$ & 0.1 & -0.8 & -0.1 & 5.4 & 0.0 & 0.0 & 0.0 & -1.9 \\
\hline $2000 \mathrm{~s}$ & -0.3 & -0.5 & 0.0 & 8.8 & -0.4 & -3.1 & -0.6 & 9.0 \\
\hline \multicolumn{9}{|l|}{ July: } \\
\hline $1970 \mathrm{~s}$ & -0.5 & -0.7 & 0.0 & 13.3 & -0.3 & -0.4 & 0.0 & -5.2 \\
\hline $1980 \mathrm{~s}$ & -0.2 & 0.5 & 0.0 & -6.5 & -0.1 & 0.4 & 0.0 & 2.6 \\
\hline $1990 \mathrm{~s}$ & -0.2 & 0.2 & 0.0 & -7.8 & -0.5 & -0.5 & 0.0 & -3.7 \\
\hline $2000 \mathrm{~s}$ & 1.0 & -0.1 & -0.2 & 1.1 & 1.1 & 0.3 & -0.2 & 7.5 \\
\hline \multicolumn{9}{|l|}{ August: } \\
\hline $1970 \mathrm{~s}$ & -0.4 & 0.6 & 0.2 & -5.5 & -0.2 & 0.7 & 0.1 & 2.2 \\
\hline $1980 \mathrm{~s}$ & -0.8 & -1.0 & 0.0 & 10.5 & -0.9 & -0.6 & 0.4 & 19.4 \\
\hline $1990 \mathrm{~s}$ & 0.2 & 0.0 & -0.1 & -4.1 & 0.1 & 0.1 & -0.1 & 1.6 \\
\hline $2000 \mathrm{~s}$ & 1.1 & 0.5 & -0.2 & -1.0 & 1.2 & -0.2 & -0.4 & -29.2 \\
\hline \multicolumn{9}{|l|}{ September: } \\
\hline $1970 \mathrm{~s}$ & -0.7 & -0.3 & 0.4 & 3.4 & -0.7 & 0.0 & -0.5 & 15.1 \\
\hline $1980 \mathrm{~s}$ & -0.1 & -0.5 & -0.4 & 11.2 & -0.1 & -0.4 & 0.7 & -2.1 \\
\hline $1990 \mathrm{~s}$ & -0.1 & 0.2 & 0.3 & -7.5 & -0.2 & -0.1 & 0.1 & -2.4 \\
\hline $2000 \mathrm{~s}$ & 1.3 & 0.9 & -0.5 & -8.9 & 1.1 & 0.6 & -0.5 & -13.0 \\
\hline
\end{tabular}




\section{AGRICULTURAL AND FOOD SCIENCE}

\section{Peltonen-Sainio, P. et al. Increases in variablity of field crops}

divergent in the 1980s as compared with the 1970s and 1990s (Fig. 2).

Radiation also varied considerably from one year to another around the total means (Fig. 2), and the range of variation differed depending on decade, however, without bearing major similarities to the yield variability ranges between and within decades (Figs 4 and 5). Variation in PTQ was highest in the 1970s and in Central Finland also in the 1980 s, while in the 2000s, when above average temperatures were recorded, it remained modest and mainly below the total mean, in contrast to the 1990s when variation was also modest but evenly distributed around the total mean. When comparing monthly means of PTQ for each decade, most variation occurred early (May) in the growing season, while particularly in June-August the variability in PTQ was modest (Table 7).

Variation in accumulated precipitation per growing season was considerable, ranging from 160 to $500 \mathrm{~mm}$ during the last four decades (Fig. 2). Particularly in southern Finland, almost all growing seasons of the 1980s were wetter than the long-term mean. In contrast, the 1970s was the decade with exceptionally low amounts of accumulated precipitation during the growing season, especially in Central Finland. When evaluating mean precipitation on a monthly basis we noticed that in the 1980 s precipitation was above the mean in all months except July in southern Finland and September in Central Finland (Table 7). In the 1970s, again, precipitation was mostly lower than average in early summer (May and June).

\section{Discussion}

Yield variability has been exceptionally high under the northernmost European growing conditions of Finland, in the 1980s and 1990s, when compared with the preceding decades (Figs 3 and 4, Table $3)$. However, since then national yields have been exceptionally stable over the 2000s. Therefore, no signs of consistently increased yield variability were recorded according to the long-term datasets of national yields. This was especially the case for cereals, and dry and green pea, for which yield trends also levelled off or even slightly decreased more lately. Also rapeseed yields declined, but with a more stable yield variability over the years and decades than for cereals and pea. A very high variation in rapeseed yields was recorded in the 1960s. However, at that time rapeseed was a novel crop in Finland and it was grown only on about 6000 hectares without comprehensive expertise on its management (Table 2). No similar drastic changes in growing areas were recorded for other species, although the area under winter rye has fallen markedly without being associated with changes in yield variability. No marked changes between decades in a generally rather high variability of national potato yields occurred during this study period of about five decades (Figs 3 and 4), in contrast to other crops, but very similar patterns of fluctuation in yields were recorded in all the major seed crops grown in Finland.

In a similar way as fluctuations between decades in national yields, the range of within year variation was high in the 1980s and 1990s, and especially for cereals other than barley (Fig. 5). Within year variability in barley yields increased similarly to that in rapeseed from one decade to the next, while in pea it fluctuated more irregularly and in potato variability was relatively constant over the different decades. Among the yield components the range of within year variability in grain number per square metre was far higher than that in single grain weight, similarly as for rapeseed (Tables 4 and 5). These findings are consistent with those recently reported by Peltonen-Sainio et al. (2007) and Peltonen-Sainio and Jauhiainen (2008), which also indicated that grain or seed number strongly determines yield formation. In this study we demonstrated trends of increasing range of variability since the 1970s in grain or seed number per square metre in spring wheat, winter rye and turnip rape.

Why did the increasing yield variability up to the 1990s suddenly change in many of the grain and seed crops and become more stable than recorded in the preceding decades? Peltonen-Sainio et al. (2009d) recently showed that yield trends of cereals have levelled off or declined during the 
Vol. 18 (2009): 206-222.

last $10-15$ years mainly because cereal production in Finland has become less intensive. The main reason for that has been introduction of an environmental programme aimed at increasing the sustainability of agriculture by reducing the environmental load it represents, and a markedly reduced economic optimum of inputs as producer prices for cereals decreased and input prices remained unchanged (Peltonen-Sainio et al. 2009d). Hence, yield trends declined despite marked and steady genetic improvements in the cereal yield potential (Peltonen-Sainio et al. 2009d). Therefore, it is possible that in the 2000s use of inputs (such as nitrogen and phosphorus, but including pesticides) have been insufficient to produce the high yields. Thereby maximum yields will be reduced, and this partly contributes to the exceptionally low variability in yields. In general there is abundant variability in climatic conditions in the northern regions typical for Finland. However, when inputs are not adequate for high yield responses, crop stands have not been able to benefit as much as in earlier decades from the favourable growing seasons. Hence, at least partly due to this, variability in yields has remained very low.

Input use in the 1980s and at least partly also in the 1990s contrasted with that in the 2000s and the high yield potential crops were able to benefit from favourable growing seasons, leading to considerable yield variability within the two decades. On the other hand, input use probably contributes to the difference between the 1980s and earlier decades. Peltonen-Sainio et al. (2009d) characterised 1960-1980 as a period when agriculture became mechanised and when improved basic agricultural practices were largely introduced, while in 19811994 intensified crop management practices were increasingly applied to utilise better the improved genetic yield potential of the modern cultivars. The reduced variability recorded for decades earlier than the 1980s was likely, at least partly, attributable to the differences in intensity of input use and consequent responsiveness of the crops.

It is probable that climatic conditions per se also contributed to the differences in yield performance of the major field crops in different decades, and between years, not solely through input inter- actions as described above. Our results suggest this to be true especially when considering the exceptionally low yield variability in the 2000 s. We established that in contrast to other decades, average temperatures for the growing seasons in the 2000s were clearly and almost consistently above the long term mean (at most by some $2{ }^{\circ} \mathrm{C}$ ) both in southern and central Finland (Fig. 2).

Peltonen-Sainio et al. (2009c) concluded that the recorded temperatures during the growing seasons of the 2000s were very similar to, but even exceeded those expected according to IPCC SRESscenarios (IPCC 2000 and 2007). An increased daily mean temperature during the yield determination phase enhances rate of development of the crops and often results in decreased floret and grain or seed set (Ugarte et al. 2007, Peltonen-Sainio et al. 2009b), especially under northern growing conditions where development is exceptionally rapid due to the long days (Peltonen-Sainio and Rajala 2007, Peltonen-Sainio et al. 2009a). However, when we calculated the monthly means for temperature during the growing season in different decades, we noticed that in the 2000s monthly temperatures were elevated except in June, at the most critical phase of yield determination (Table 7). However, for rapeseed and particularly for spring turnip rape, increased temperature during seed filling in the 2000s explains part of the recorded yield reductions, modern turnip rape cultivars being sensitive to high temperatures during seed filling (PeltonenSainio et al. 2007).

We established considerable variability in accumulated precipitation from May to the end of September although the range of variability within each decade did not parallel that in yield performance. When studied in more detail, we noted that in the 2000s in general, precipitation was above average during the early summer months, from May to July (Table 7). These months fully cover the crop phases that are most critical for yield determination in grain and seed crops, while the recorded reduced precipitation in August and September in the 2000s likely favoured harvesting and thereby enhanced crop quality. Even though precipitation was generally higher during the entire period for yield determination in the 2000s in Finland, it does 
Peltonen-Sainio, P. et al. Increases in variablity of field crops

not imply that precipitation was evenly distributed. Considering climate change effects, all the extreme events, including heat waves and heavy rains, are expected to become more frequent (IPCC 2007). Therefore, we looked at whether there were any recorded changes in distribution of rainfalls in different decades.

We found that only in June had the number of days with precipitation $>5 \mathrm{~mm}$ systematically increased. In the 1970s the mean number of June days with $>5 \mathrm{~mm}$ precipitation was 2.8 , in the $1980 \mathrm{~s}$ it was 3.5 , in the $1990 \mathrm{~s} 4.0$ and in the $2000 \mathrm{~s}$ 4.5. There was also a similar trend in number of days with $>5 \mathrm{~mm}$ precipitation in May, although interpretation was not as straightforward as for June data (data not shown). However, when comparing the frequencies of days with $>10 \mathrm{~mm}$ and 20 $\mathrm{mm}$ precipitation, the 2000 s were not exceptional. Moreover, only an increase in daily precipitation $>20 \mathrm{~mm}$ can truly be considered a heavy shower and a possible indication of unevenness in precipitation within a single month. Therefore, in light of these findings on fluctuations in both temperature and precipitation, lack of yield increase or yield reduction, especially in cereals and pea, were not expected to occur in the 2000 s, especially when compared with our recent findings of prominent crop responses to these factors under northern growing conditions (Peltonen-Sainio et al. 2009b). This further emphasises the role of insufficient input use in reduced yield variability.

Typically also many quality traits fluctuate depending on growing conditions, and this was evident also in this study, although in most cases there were no clear trends concerning changes in variability between decades (Tables 4, 5, and 6). However, in the 2000s grain protein content was more stable in oat and winter rye, which is likely attributable to stable yields. In contrast to rapeseed variability in plant height and lodging of cereals was slightly reduced in the 2000 s after being quite stable earlier, while in pea it was consistently reduced. These findings for cereals and pea, together with the recorded stable yields in the 2000s, again suggest possible insufficient input use, especially regarding nitrogen. Another interesting trend was in variability of rapeseed seed chlorophyll content.
That one declined even by the use of long-term check cultivars only, which largely eliminated the effect of cultivar development on seed chlorophyll content.

In conclusion, yield variability was exceptionally high in the 1980s and 1990s, while stable and reduced or stagnated yields were recorded in the 2000s. This was true for all crops except potato. We also noticed that in the 2000s mean temperature was higher than in earlier decades, and also precipitation increased during the first three months of the growing season and thereafter decreased, without signs of significantly increased number of heavy showers (extreme rain events). Hence, in general, increased mean temperature during the growing seasons of the 2000s was identified, but with reduced yield variability and crop responsiveness, which was at least partly attributable to the reduced use of inputs, especially fertilisers.

Acknowledgements. The authors are grateful to the numerous partners who have participated in organising the MTT Official Cultivar Trials since 1970. The work was financed by Finnish Ministry of Agriculture and Forestry and MTT Agrifood Research Finland as a part of an on-going consortium project entitled Adaptation of Finnish Agro-food Sector to Climate Change (ILMASOPU) for 2006-2009, which belongs to National Climate Change Adaptation Program, ISTO.

\section{References}

Alexander, L.V., Zhang, X., Peterson, T.C., Caesar, J., Gleason, B., Klein Tank, A.M.G., Haylock, M., Collins, D., Trewin, B., Rahimzadeh, F., Tagipour, A., Rupa Kumar, K., Revadekar, J., Griffiths, G., Vincent, L., Stephenson, D.B., Burn, J., Aguilar, E., Brunet, M., Taylor, M., New, M., Zhai, P., Rusticucci, M. \& Vazquez-Aguirre, J.L. 2006. Global observed changes in daily climate extremes of temperature and precipitation. Journal of Geophysical Research 111. 22 p.

Carter, T.R. 1998. Changes in the thermal growing season in Nordic countries during the past century and prospects for the future. Agricultural and Food Science in Finland 7: 161-179.

Carter, T.R., Saarikko, R.A. \& Niemi, K.J. 1996. Assessing the risks and uncertainties of regional crop potential under a changing climate in Finland. Agricultural and Food Science in Finland 5: 329-350.

Fischer, R.A. 1985. Number of kernels in wheat crops and 
Vol. 18 (2009): 206-222.

the influence of solar radiation and temperature. Journal of Agricultural Science Cambridge 105: 447-461.

IPCC 2000. Emissions Scenarios. Special Report of the Intergovernmental Panel on Climate Change. N. Nakicenovic and R. Swart (eds.), Cambridge University Press, Cambridge, England, 570 p.

IPCC 2007. Summary for Policymakers. In: Climate Change 2007: The Physical Science Basis. Contribution of Working Group I to the Fourth Assessment Report of the Intergovernmental Panel on Climate Change. Solomon, S., D. Qin, M. Manning, Z. Chen, M. Marquis, K.B. Averyt, M. Tignor \& H.L. Miller (eds.). Cambridge University Press, Cambridge, United Kingdom and New York, NY, USA.

Jylhä, K., Fronzek, S., Tuomenvirta, H., Carter, T.R. \& Ruosteenoja, K. 2008. Changes in frost, snow and Baltic sea ice by the end of the twenty-first century based on climate model projections for Europe. Climatic Change 86: 441-462.

Kangas, A., Laine, A., Niskanen, M., Salo, Y., Vuorinen, M., Jauhiainen, L. \& Nikander, H. 2005. Results of official variety trials 1997-2005. MTT:n selvityksiä 83. Kasvintuotanto. 192 p. (Partly in English).

Kaukoranta, T. \& Hakala, K. 2008. Impact of spring warming on sowing times of cereal, potato and sugar beet in Finland. Agricultural and Food Science 17: 165-176.

Klein Tank, A.M.G. \& Wijngaard, J.B., et al., 2002. Daily dataset of 20th-century surface air temperature and precipitation series for the European Climate Assessment. International. Journal of Climatology 22: 1441-1453.

Klein Tank, A.M.G. \& Können, G.P. 2003. Trends in indices of daily temperature and precipitation extremes in Europe, 1946-1999. Journal of Climate 16: 3665-3680.

Olesen, J.E. \& Bindi, M. 2002. Consequences of climate change for European agricultural productivity, land use and policy. European Journal of Agronomy 16: 239262.
Peltonen-Sainio, P. \& Rajala, A. 2007. Duration of vegetative and generative development phases in oat cultivars released since 1921. Field Crops Research 101: 72-79.

Peltonen-Sainio, P. \& Jauhiainen, L. 2008. Association of growth dynamics, yield components and seed quality in long-term trials covering rapeseed cultivation history at high latitudes. Field Crops Research 108: 101-108.

Peltonen-Sainio, P., Jauhiainen, L. \& Hannukkala, A. 2007. Declining rapeseed yields in Finland: how, why and what next? Journal of Agricultural Science in Cambridge 145: 587-598.

Peltonen-Sainio, P., Rajala, A., Känkänen, H. \& Hakala, K. 2009a. Improving farming systems in northern European conditions. In: Crop Physiology: Applications for Genetic Improvement and Agronomy. V.A. Sadras \& D.L. Calderini (eds). Elsevier, published, p. (page numbers to be updated when available).

Peltonen-Sainio, P., Jauhiainen, L. \& Hakala, K. 2009b. Crop responses to temperature and precipitation according to long-term multi-location trials at high latitudes with reference to climate change. Manuscript submitted.

Peltonen-Sainio, P., Hakala, K., Jauhiainen, L. \& Ruosteenoja, K. 2009c. Comparing regional risks in producing turnip rape and oilseed rape - Impacts of climate change and breeding. Acta Agriculturae Scandinavica, B Plant and Soil Science 59: 129-138.

Peltonen-Sainio, P., Jauhiainen, L. \& Laurila, I.P. 2009d. Cereal yield trends in northern European conditions: changes in yield potential and its realisation. Field Crops Research 110: 85-90.

Ugarte, C., Calderini, D.F. \& Slafer, G.A. 2007. Grain weight and grain number responsiveness to pre-anthesis temperature in wheat, barley and triticale. Field Crops $R e$ search 100: 240-248. 


\title{
SELOSTUS
}

\section{Onko viljelykasviemme vuotuinen satovaihtelu kasvanut ilmaston muuttuessa?}

\author{
Pirjo Peltonen-Sainio, Lauri Jauhiainen ja Kaija Hakala
}

Ilmastonmuutos lisää tuotannon epävarmuutta, koska sääolojen vaihtelu lisääntyy ja sään ääri-ilmiöt yleistyvät. Satoerot suotuisien ja epäsuotuisien kasvukausien välillä korostuvat myös lajikkeiden sadontuottokyvyn lisääntymisen vuoksi. Nykylajikkeiden korkean perinnöllisen satopotentiaalin toteutuminen edellyttää lisäksi riittävää tuotantopanosten, erityisesti ravinteiden, käyttöä. Koska kasvintuotantomme on kokenut merkittäviä muutoksia viimeisten vuosikymmenten aikana, tarkastelimme pitkäaikaisaineistojen (FAO 1960-luvulta ja MTT:n viralliset lajikekokeet 1970-luvulta lähtien) perusteella, voidaanko satovaihtelussa nähdä jaksottaisia systemaattisia muutoksia. MTT:n aineistoja käyttäen tutkittiin vuosien sisäistä vaihtelua sekä vaihtelua keskeisimmissä laatutekijöissä. Tutkimuksen tavoitteena oli arvioida onko sato- ja laatuvaihtelu yleistynyt viljelykasvien satoisuuden kasvun myötä ja onko ilmastonmuutos jo vahvistanut tätä ilmiötä. Tarkastelimme satovaihtelun muutoksia vuosikymmenittäin.

Tuloksemme osoittivat, ettei sato- ja laatuvaihtelussa oli systemaattista kasvua tarkasteluperiodillamme. Ainoa poikkeus oli öljykasvit, joiden sadon lehtivihreäpitoisuus ja siinä ilmenevä vaihtelu on jatkuvasti vähentynyt. Satovaihtelu oli runsainta 1980- ja 1990-luvuilla, paitsi perunalla, jolla vaihtelu on ollut varsin samanlaista koko tarkastelujakson ajan. Toisaalta öljykasveilla vaihtelu oli suurta myös 1960-luvulla, mikä selittynee rypsin lyhyellä viljelyhistorialla ja tämän silloin aivan uuden kasvilajin viljelyyn ottoon liittyvillä alkuvaikeuksilla. Muilla siemensatokasveilla satoisuus vaihteli hyvin vähän tarkastelujakson alkupuolella. Ilmeisesti suotuisien vuosien sadot eivät poikenneet suuresti heikkojen vuosien sadoista, koska tuotantopanoksia käytettiin rajallisesti ja modernien viljelymenetelmien kehitystyö oli vasta alkutaipaleellaan.

Yllättävin havainto oli kuitenkin kaikilla siemensatokasveilla havaittu satoisuuden vaihtelun merkittävä väheneminen 2000-luvun aikana. Ilmiö ei selity yksinomaan säällä, sillä myös 2000-luvulla esiintyi jokunen suotuisa kasvukausi, jolloin satojen olisi pitänyt olla keskimääräistä suurempia. Onkin luultavaa, että kuluvan vuosikymmenen poikkeuksellisen maltillinen satovaihtelu johtuu tuotantopanosten käytön vähenemisestä (erityisesti kasviravinteet ja kasvinsuojelu), jolloin suotuisinakaan vuosina sadot eivät nousseet nykylajikkeiden potentiaalin mukaisesti. Toisaalta 2000-luvun tasaantuneiden tai jopa laskeneiden satojen vähäisen vuosivaihtelun selittää myös havaintomme, jonka mukaan ilmastonmuutosennusteiden mukaisesti todennetut, kohonneet päivittäiset keskilämpötilat, vieläpä kohdistuen juuri kriittisimpään sadon määräytymisen aikaan, ovat aiheuttaneet satotappioita kiihdytettyään liiaksi kevätkylvöisten siemensatokasvien kehitysrytmiä. Näistä syistä johtuen viime vuosikymmenien aikana lisääntyneet satovaihtelut ovat nyt 2000-luvulla kaventuneet poikkeuksellisen vähäisiksi. 